\title{
Comparison of sinking and sedimentation rate measurements in a diatom winter/spring bloom
}

\author{
Ulf Riebesell*
}

Graduate School of Oceanography, University of Rhode Island, Narragansett, Rhode Island 02882-1197, USA

\begin{abstract}
Sinking and sedimentation rates of a natural phytoplankton community were simultaneously measured during the course of a diatom winter/spring bloom in a $13 \mathrm{~m}^{3}$ experimental mesocosm. Sinking rate was determined directly in settling columns and was calculated from sediment trap catches. The 2 methods yielded significantly different results. Whole-community as well as speciesspecific sinking rates varied over time. These variations were related to changes of the environmental conditions. Over a $26 \mathrm{~d}$ study period, a total of $7.5 \mathrm{~g} \mathrm{C} \mathrm{m}^{-2}$ was collected in the sediment traps. Viable phytoplankton cells were the primary component of the sedimented matter while zooplankton fecal pellets contributed on average less than $10 \%$. Assuming the Redfield atomic ratio for the collected material, the amount of carbon which sedimented during the winter/spring bloom could be predicted from pre-bloom nutrient concentrations. The daily sedimentation rate varied considerably over time and displayed a characteristic pattern. This pattern is evidently a function of both suspended phytoplankton biomass and the temporal variation in whole-community sinking rate.
\end{abstract}

\section{INTRODUCTION}

Results obtained with sediment traps indicate a marked seasonal variation in the downward flux of organic matter. It has been well documented that sedimentation in the form of fresh phytoplankton material is highest during periods of new production in shelf seas (Hargrave \& Taguchi 1978, Smetacek et al. 1978, Davies \& Payne 1984, Smetacek 1984, Christensen \& Kanneworff 1985), as well as in the deep sea (Deuser \& Ross 1980, Honjo 1982, Billett et al. 1983). A large proportion of the annual flux of biogenic material has been observed to occur in the form of rapid mass sedimentation over a very short period immediately following phytoplankton blooms (Smetacek 1980, Jewson et al. 1981, Peinert et al. 1982, Reynolds et al. 1982a, Wassmann 1983, Rudnick 1984, Lampitt 1985).

Recent developments in phytoplankton research have emphasized the importance of loss processes in the explanation of algal species succession (Kalff \& Knoechel 1978, Smayda 1980, Reynolds et al. 1982b). One of the most prominent loss processes is particle sinking. Numerous laboratory studies on sinking of

\footnotetext{
- Present address: Alfred Wegener Institute for Polar and Marine Research, Columbusstrasse, D-2850 Bremerhaven, Federal Republic of Germany
}

cultured phytoplankton have shown that sinking rates are determined by physical factors associated with cell size and shape, as well as by the physiological properties of the cell (Steele \& Yentsch 1960. Smayda \& Boleyn 1965, 1966a,b, Eppley et al. 1967a,b, Akinana 1969, Walsby 1969, 1970, Dinsdale \& Walsby 1972, Reynolds 1973, Andersen 1974, Titman \& Kilham 1976).

The difficulties involved in extrapolating findings obtained from unialgal laboratory studies to the behavior of multispecies assemblages in nature led to the development of techniques suitable for the analysis of natural phytoplankton populations (Rothwell \& Bienfang 1978, Bienfang 1979, Lännergren 1979). Recently, a relatively simple technique called SETCOL was developed to measure the sinking rate of particulate matter in the field (Bienfang 1981a). This method has been frequently applied in various geographical regions with results revealing a dependency of sinking rate on phytoplankton cell size (Smayda \& Bienfang 1983, Bienfang 1984, Jacques \& Hoepffner 1984), ambient light intensity (Bienfang et al. 1983, Bienfang 1985, Johnson \& Smith 1986), and nutrient concentrations (Bienfang 1981b, Bienfang et al. 1982, Bienfang \& Harrison 1984).

The trapping of sedimenting matter to obtain sedimentation rates, and the measurement of phytoplankton 
sinking rates both address the same question, namely, what is the downward flux of phytoplankton material. Nevertheless, to date the 2 variables have been treated as mutually independent and there have been no studies which simultaneously employed both approaches, Consequently, very little is known about the relationship between sinking and sedimentation rates.

To study the connection between these 2 variables, an experiment was conducted to simultaneously measure the sinking and sedimentation rates of a natural phytoplankton community in a non-advective environment. A mesocosm of the Marine Ecosystems Research Laboratory (MERL), located at the Graduate School of Oceanography, University of Rhode Island, USA, was employed. The main objectives of the study were: (1) to compare and correlate sinking and sedimentation rates of a natural phytoplankton community to each other and to the physical, chemical, and biological conditions of the experimental environment, and (2) to seek evidence for a phytoplankton sinking pattern which might be responsible for the strong, short-term variability in sedimentation documented to occur during the course of phytoplankton blooms.

\section{METHODS}

A mesocosm (volume: $13 \mathrm{~m}^{3}$, water depth: $5 \mathrm{~m}$ ) of the Marine Ecosystem Research Laboratory (MERL) was filled with seawater from Narragansett Bay before the onset of the winter/spring bloom $1 \mathrm{~d}$ prior to the beginning of the experiment. Over a $26 \mathrm{~d}$ period ( 7 February to 4 March 1987), the course of the bloom was closely monitored in the tank.

The water column was mixed with a horizontal mixing device (configuration adapted from Donaghay \& Klos 1985), which was set up to fulfill 2 objectives: (1) to ensure well-mixed conditions in the upper $4.0 \mathrm{~m}$ of the water column at all times, and (2) to prevent the resuspension of sedimented material. Based on results from pre-experimental tests, the mixing rate and schedule required to fulfill the 2 objectives were found to be 3.5 rotations $\mathrm{min}^{-1}$ and a continuous cycle with $1.5 \mathrm{~min}$ each of clockwise rotation, rotation stop, and counterclockwise rotation.

A daily record of the water temperature in the mesocosm was obtained with a thermistor sensor placed at a depth of $1 \mathrm{~m}$. Both temperature and salinity profiles (measured in $0.5 \mathrm{~m}$ depth intervals) were recorded weekly using a Beckman Model RS5-3 induction salinometer. Photosynthetically active radiation (400 to $700 \mathrm{~nm}$ ) at the surface was measured with a LI-COR, LI-190S quantum sensor. Vertical profiles within the tanks were taken with a cosine corrected LI-COR, LI$192 \mathrm{~S}$ quantum sensor.
Nutrient concentration, chlorophyll a, phaeopigment content, and species composition and abundance were determined daily from water samples taken at a depth of $1 \mathrm{~m}$. Depth profiles of chlorophyll a were measured weekly.

Dissolved inorganic nutrients $\left(\mathrm{NH}_{3}, \mathrm{NO}_{2}{ }^{-}, \mathrm{NO}_{3}{ }^{-}\right.$. $\mathrm{PO}_{4}{ }^{-3}$, and $\mathrm{SiO}_{4}^{-4}$ ) were analysed on a Technicon Autoanalyser according to the methods described in Kelly \& Beach (1986). All nutrient samples were filtered through $0.6 \mu \mathrm{m}$ Nucleopore filters prior to analysis.

To initiate bloom conditions in the experimental mesocosm, a single nutrient addition $\left(14 \mu \mathrm{mol} \mathrm{NH}_{4} \mathrm{Cl}\right.$ $\mathrm{l}^{-1}, 1.1 \mathrm{\mu mol} \mathrm{KH}_{2} \mathrm{PO}_{4} \mathrm{l}^{-1}$, and $13.5 \mathrm{umol} \mathrm{NaSiO} \cdot 9 \mathrm{H}_{2} \mathrm{O}$ $1^{-1}$ ) was supplied to the system at the start of the experiment. This procedure doubled the concentration of nutrients measured in the input water at the time of the fill on 6 February 1987.

Chlorophyll a and phaeopigment were measured fluorometrically (Strickland \& Parsons 1972). Replicate $10 \mathrm{ml}$ aliquots of sample water were filtered onto Whatman $25 \mathrm{~mm} \mathrm{GF/F} \mathrm{glass} \mathrm{fiber} \mathrm{filters} \mathrm{(} 1 \mu \mathrm{m}$ particle retention), frozen, extracted with $90 \%$ acetone, and read on a Turner Design Model 10 Field Fluorometer. Variability inherent in the analysis was reduced using the dual standard method (Donaghay unpubl.).

Floristic analyses of live samples were performed immediately after sampling, while cell counts on samples preserved in Lugol's iodine solution were made using the inverted microscope method of Utermöhl (1958), as detailed in Hasle (1978). Cell volumes were calculated according to Kovala \& Larrance (1966) on the basis of cell size determinations for all identified species. Cell volume was converted to phytoplankton cell carbon using the equations formulated by Eppley et al. (1970). Total phytoplankton carbon was calculated by summing the products of the species cell numbers and the carbon content per cell.

Six sediment traps were installed in the tank such that the trap openings were positioned $50 \mathrm{~cm}$ above the bottom of the tank and $70 \mathrm{~cm}$ below the lowest mixing paddle. The traps, built of clear plexiglass with a $4.5 \mathrm{~cm}$ diameter opening and a height of $20 \mathrm{~cm}$, were evenly spaced over half the tank diameter. The trapped material was collected every $24 \mathrm{~h}$ by slowly lifting the entire trap array to the water surface while mixing was stopped. The collected material was always concentrated in the bottom $1 \mathrm{~cm}$ of the traps, indicating that it remained indisturbed during trap removal. No preservatives were applied in the traps.

Single traps were removed from the trap holders and placed on an inverted microscope for immediate examination of the undisturbed samples. After this first examination, aliquots were taken for the analysis of chlorophyll $a$ and phaeopigment. The remaining sample was preserved with Lugol's iodine solution for later 
determination of phytoplankton cell numbers and fecal pellet abundances. Fecal pellet carbon content was calculated according to the method described in Bathmann et al. (1987)

Sinking rate was estimated in 2 different ways: (1) The SETCOL homogeneous sample method (Bienfang 1981a) was used to directly assess the sinking rate (termed $\Psi_{\text {SETCOL }}$ ) in settling columns. Communitymean sinking rates, as well as species-specific rates, were determined from the change in the vertical distribution of biomass after a given period of time. Chlorophyll a was used as the biomass index to calculate total-community sinking rates, and cell numbers were obtained to calculate species-specific sinking rates. During the $4 \mathrm{~h}$ settling period (12:00 to $16: 00 \mathrm{~h}$ ), the SETCOL apparatus was exposed to natural light. The columns were covered with neutral density screening to simulate light conditions at a $1 \mathrm{~m}$ depth in the experimental tank. (2) Sediment trap catches were used to calculate sinking rate (termed $\Psi_{\text {TRAP }}$ ). For the parameters chlorophyll $a$ and phaeopigment and for 5 different phytoplankters, the following formula (adapted from Reynolds 1976) was used:

$$
\Psi_{\text {TRAP }}=\mathrm{S}_{\mathrm{D}} / \mathrm{B}_{\mathrm{P}} \quad\left(\text { in } \mathrm{m} \mathrm{d}^{-1}\right)
$$

where $S_{D}=$ daily sedimentation rate $\left(\mathrm{mg} \mathrm{m}^{-2} \mathrm{~d}^{-1}\right.$ or cells $\mathrm{m}^{-2} \mathrm{~d}^{-1}$ ); and $\mathrm{B}_{\mathrm{p}}=$ phytoplankton biomass $(\mathrm{mg}$ $\mathrm{m}^{-3}$ or cells $\mathrm{m}^{-3}$ ).

\section{RESULTS}

\section{General conditions in the mesocosm}

The water temperature in the mesocosm varied irregularly over time between 0.8 and $3.0^{\circ} \mathrm{C}$. Salinity remained constant at about $32 \%$. Weekly salinity and temperature profiles indicated constant salinity values with depth while the temperature decreased slightly by about 0.2 to $0.3^{\circ} \mathrm{C}$ below $4 \mathrm{~m}$ depth.

The nutrient concentrations and phytoplankton standing stock (Fig. 1a and b) followed the classic pattern observed in many coastal temperate regions during a phytoplankton winter/spring bloom (Parsons et al. 1984). A rapid uptake of dissolved inorganic nutrients greatly decreased the concentrations of ammonium, nitrate, phosphate, and silica during the first $10 \mathrm{~d}$ of the experiment. While nitrate dropped below the detection limit on Day 11, the other 3 nutrients remained approximately constant at a level below $0.3 \mu \mathrm{M}$. Silica concentration fell below the detection limit on Day 19.

Concurrent with the decrease in nutrients, phytoplankton biomass increased exponentially until nutrients became limiting (Fig. 1b). A short period of
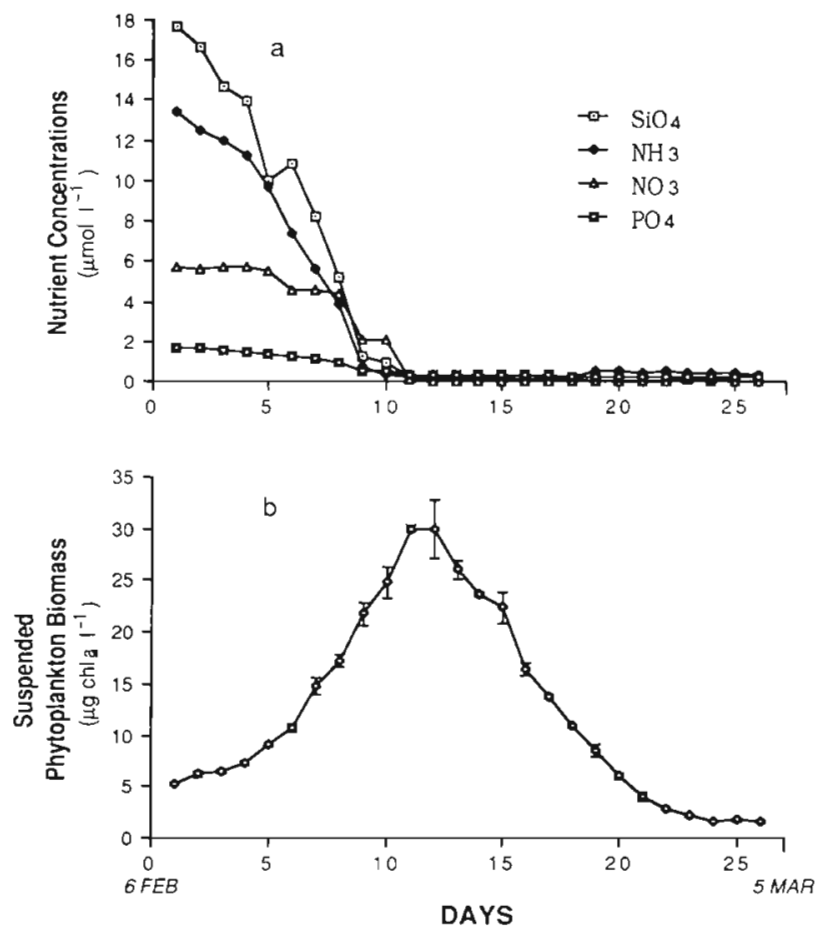

Fig. 1. (a) Concentrations of dissolved inorganic nutrients; (b) phytoplankton biomass in the experimental tank over the course of the study. Error bars in (b) represent 1 standard deviation $(n=2)$

steady state biomass was followed by a rapid decrease of phytoplankton biomass between Days 12 and 23. From Day 24 on, biomass equilibrated at about $1.6 \mu \mathrm{g}$ chl a $1^{-1}$. Weekly depth profiles of chlorophyll a indicated that the phytoplankton biomass was evenly distributed in the mixed, upper $4.0 \mathrm{~m}$ of the water column.

During the entire bloom period (Days 1 to 20), the phytoplankton community was dominated by the

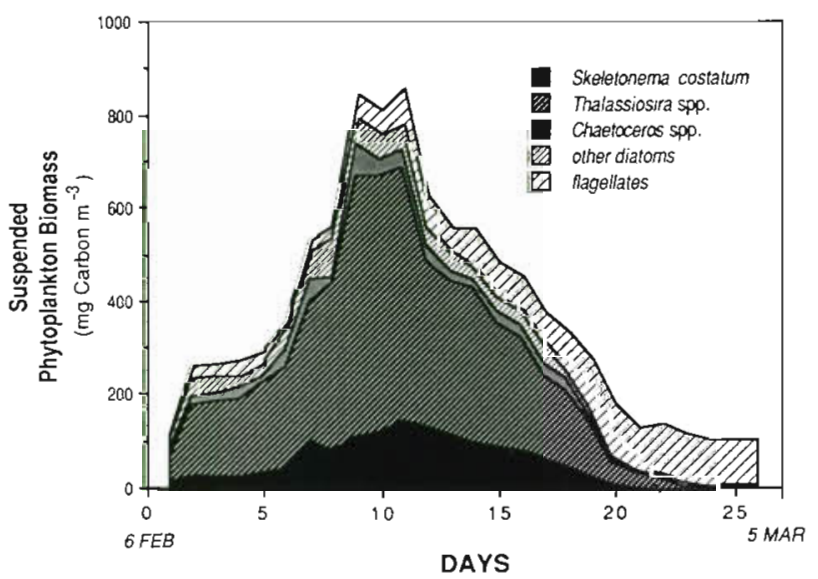

Fig. 2. Phytoplankton biomass (mg $\mathrm{Cm}^{-3}$ ) of 5 different groups. Phytoplankton carbon was estimated by multiplying the number of cells counted for each group with the cell carbon content, which was calculated from cell volume according to Eppley et al. (1970) 
diatoms Skeletonema costatum and Thalassiosira spp. (Fig. 2). The genus Thalassiosira alone contributed more than $55 \%$ to the total community biomass during this period. The disappearance of most of the diatoms and a slight increase in the number of flagellates by Day 20 resulted in a shift from a diatom- to a flagellatedominated community. Between Day 24 and the end of the experiment, more than $90 \%$ of the phytoplankton community consisted of flagellates.

Throughout the experiment the zooplankton population was dominated by the copepod Acartia hudsonica and by larvae of the barnacle Semibalanus balanoides.

\section{Phytoplankton sedimentation}

The material collected in the sediment traps consisted largely of long chains of viable (i.e. chlorophyll acontaining) phytoplankton cells. White, fluffy aggregates with entangled diatom chains first occurred in the sediment traps shortly after the peak of the bloom (Days 10 to 11), and increased in abundance during the decline of the bloom. The contribution of fecal pellets to the sedimented material was consistently low, ranging between 5 and $15 \%$ of the total sedimented carbon.

Over the $26 \mathrm{~d}$ study period, a total of $7.47 \mathrm{~g} \mathrm{C} \mathrm{m}^{-2}$ or $622 \mathrm{mmol} \mathrm{C} \mathrm{m}^{-2}$ sedimented out of the water column. Assuming the Redfield (1958) atomic ratio of $\mathrm{C}: \mathrm{N}: \mathrm{P}=$ 106:16:1 for the sedimented material, the carbon flux measured would imply a sedimentation of $93.9 \mathrm{mmol}$ $\mathrm{Nm}^{-2}$ and $5.9 \mathrm{mmol} \mathrm{Pm}^{-2}$. At the beginning of the experiment ( $7 \mathrm{Feb}$ ), the amounts of dissolved inorganic nitrogen and phosphorus integrated over the water column were $86.7 \mathrm{mmol} \mathrm{N} \mathrm{m}{ }^{-2}$ and $7.5 \mathrm{mmol} \mathrm{Pm}^{-2}$, respectively. Based on the estimated sedimentation for nitrogen and phosphorus over the course of the winter/ spring bloom, $108 \%$ of the inorganic nitrogen and $79 \%$ of the inorganic phosphorus present before the initiation of the bloom sedimented out of the water column. A value of more than $100 \%$ for sedimented nitrogen can be accounted for by a $\mathrm{C}$ to $\mathrm{N}$ ratio greater than the assumed value, by sources of dissolved organic nitrogen ending up as particulate nitrogen, or, less likely, by molecular nitrogen fixation. The close agreement between the concentrations of dissolved inorganic nitrogen and phosphorus and their respective flux to the bottom, suggests that the total flux of material over the course of the winter/spring bloom can be predicted from pre-bloom nutrient concentrations.

Daily chlorophyll $a$ and phytoplankton cell carbon sedimentation (Fig. 3) displayed a pattern very similar to the standing stock curve. A continuous increase during the first $11 \mathrm{~d}$ was followed by a rapid decrease
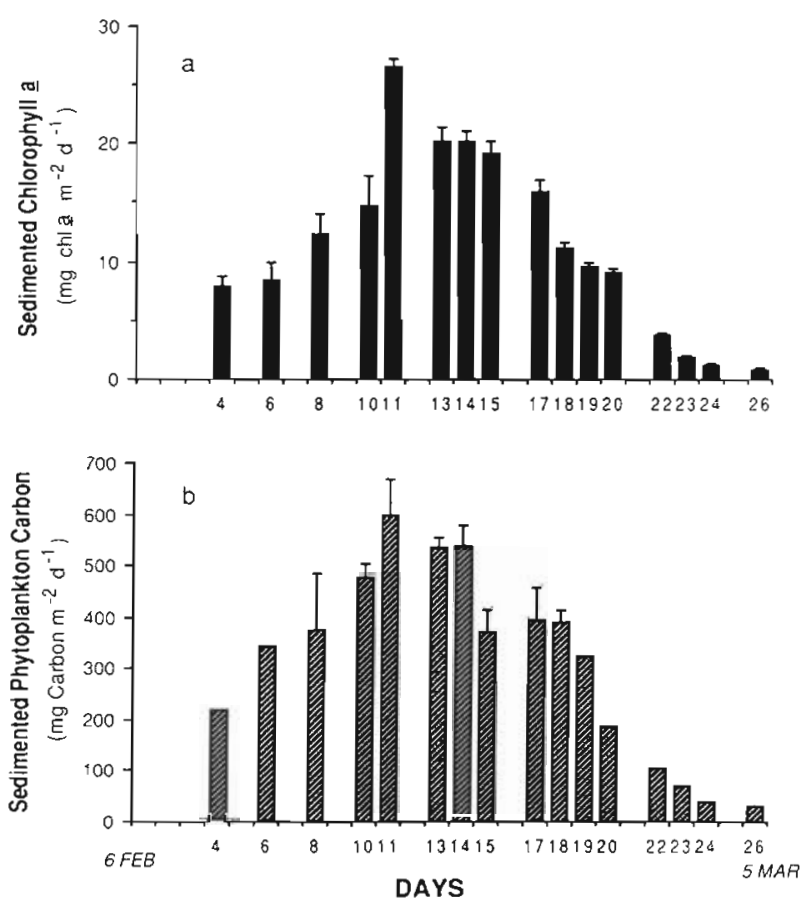

Fig. 3. Amount of chlorophyll a and phytoplankton carbon collected in the sediment traps. Error bars indicate 1 standard deviation $(n=6)$

over the subsequent $13 \mathrm{~d}$. A plot of suspended versus sedimented phytoplankton carbon revealed a strong positive relationship ( $t$-test: $p<0.01$ ) with a correlation coefficient of 0.90 (Fig. 4). However, a simple, direct correlation between total suspended and sedimented biomass is distorted by the fact that data points deviate from the estimated regression line in a non-random fashion. As indicated by the day numbers next to the data points, values obtained during the development of the bloom generally fall beneath the regression line

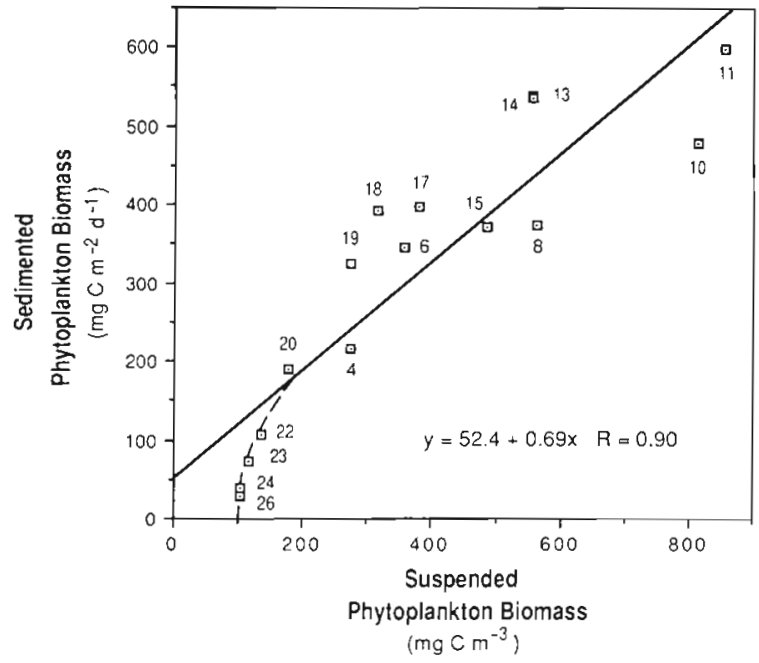

Fig. 4. Phytoplankton sedimented versus suspended biomass. Regression equation and correlation coefficient are indicated. Numbers beside data points indicate dates (e.g. $4=4$ th day of the experiment) 
Table 1. Cumulative sinking loss (cells $\mathrm{cm}^{-2}$ in sediment trap) over the $26 \mathrm{~d}$ study period compared to the maximum standing stock (cells $\mathrm{cm}^{-2}$ )

\begin{tabular}{|c|c|c|c|}
\hline Species/genus & $\begin{array}{l}\text { Cumulative sinking loss } \\
\qquad\left(\mathrm{S}_{\mathrm{c}}\right)^{\mathrm{a}}\end{array}$ & $\begin{array}{l}\text { Maximum standing stock } \\
\qquad\left(B_{\max }\right)\end{array}$ & $\begin{array}{c}\mathrm{S}_{\mathrm{C}} / \mathrm{B}_{\max } \\
(\%)\end{array}$ \\
\hline Skeletonema costatum & $2.2 \times 10^{6}$ & $2.8 \times 10^{6}$ & 79 \\
\hline Thalassiosira spp. & $11.2 \times 10^{5}$ & $5.0 \times 10^{5}$ & 224 \\
\hline Chaetoceros spp. & $3.2 \times 10^{4}$ & $37.0 \times 10^{4}$ & 9 \\
\hline Leptocylindrus minimus & $7.8 \times 10^{4}$ & $27.7 \times 10^{4}$ & 28 \\
\hline Rhizosolenia delicatula & $14.0 \times 10^{3}$ & $16.7 \times 10^{3}$ & 84 \\
\hline Rhizosolenia setigera & $9.9 \times 10^{3}$ & $9.5 \times 10^{3}$ & 104 \\
\hline
\end{tabular}

(Days $4,8,10,11$ ) signifying lower sedimentation in relation to suspended biomass. On the other hand, values recorded during the decline of the bloom are located above the line (Days 13, 14, 17, 18, 19, 20) indicating relatively higher sedimentation. After the decline of the bloom, values again fall beneath the line (Days 22, 23, 24, 26). This characteristic scheme suggests that a simple correlation between suspended and sedimented biomass is modulated by temporal changes in whole-community as well as species-specific sinking rates. The direct relationship between suspended and sedimented biomass is also contorted at the lower end of the regression line (dashed line, Fig. 4). As the suspended biomass approaches $100 \mathrm{mg} \mathrm{Cm}^{-3}$, the sedimented biomass approaches zero. This minimum suspended biomass, which is comprised of small and mainly flagellated phytoplankters, may be considered a threshold biomass. It is not subject to sedimentation and forms the basis for a regenerating community which develops after the decline of the diatom bloom.

A comparison of cumulative sinking $\left(S_{C}\right)$ with maximum standing stock $\left(B_{\max }\right)$ provides an indication of the relative importance of phytoplankton sedimentation as a loss mechanism for suspended biomass (Table 1). Values of $\mathrm{S}_{C} / \mathrm{B}_{\max }$ close to $100 \%$ suggest that the disappearance of these species from the plankton is largely due to sedimentation. While sedimentation does not appear to be a significant loss factor for Leptocylindrus minimus and Chaetoceros spp., the cumulative sinking loss of the other groups is of approximately the same magnitude as their maximum standing stock (except Thalassiosira spp.; see 'Discussion').

\section{Total-community and species-specific sinking rates}

Daily whole-community sinking rates as calculated from sediment trap catches ( $\Psi_{\text {TRAP }}$, Fig. 5) varied over time and ranged from 0.29 to $1.53 \mathrm{~m} \mathrm{~d}^{-1}$. Three welldefined phases can be distinguished and related to the life cycle of the phytoplankton community (see 'Discussion'). The variation of species-specific sinking rates over time for Skeletonema costatum, Thalassiosira spp., and Leptocylindrus minimus revealed a characteristic sinking pattern for each of these species (Fig. 6). Due to its uniformly low sinking rate throughout the study period, L. minimus remained in suspension and was able to grow to its maximum abundance after most other diatoms had disappeared from the water column. Thalassiosira spp., on the other hand, were subject to a constantly high sinking rate which further increased between Day 10, the time of their peak biomass, and Day 20, when most of the long chains had vanished from the water column and mainly short chains or single cells remained suspended. This high sinking rate acted as a drain of biomass during the entire study period and resulted in a rapid decline of the population after growth conditions became unfavorable. Two phases can be distinguished in the sinking behavior of $S$. costatum: an intermediate, relatively stable sinking rate from Day 1 to Day 17, followed by a period of rapidly increasing sinking rate (Days 18 to 23 ).

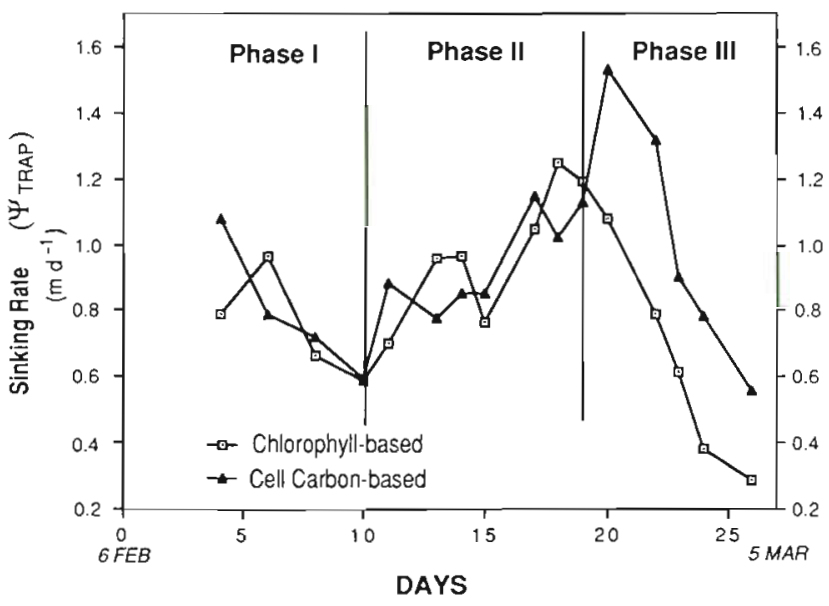

Fig. 5. Whole-community sinking rate $\left(\mathrm{m} \mathrm{d}^{-1}\right)$ as calculated from sediment trap catches. Data are derived from 2 different biomass parameters: chlorophyll a $(\mathbf{\Delta})$ and phytoplankton cell carbon ( $\square$ ) 


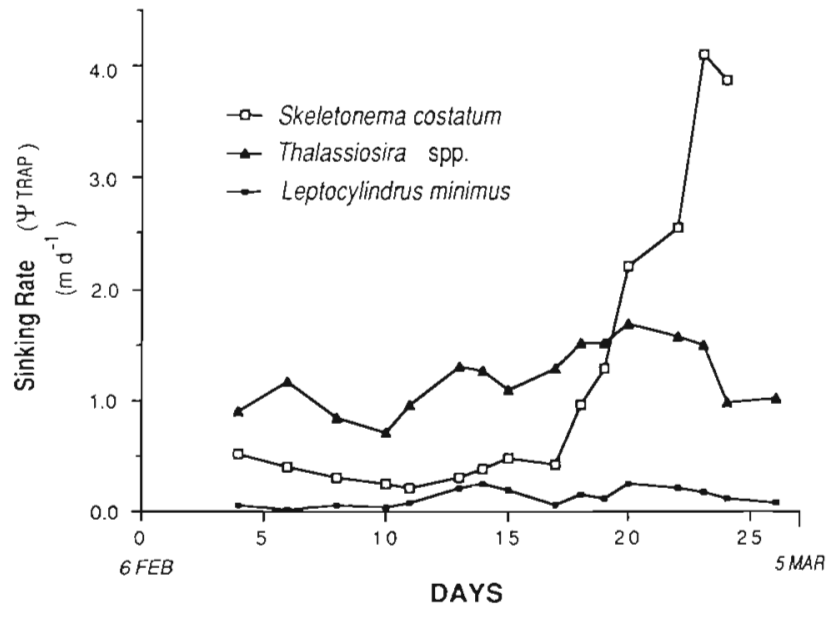

Fig. 6. Skeletonema costatum, Thalassiosira spp., and Leptocylindrus minimus. Species-specific sinking rates $\left(\mathrm{m} \mathrm{d}^{-1}\right)$ calculated from sediment trap catches

A very different pattern of daily whole-community sinking rate emerges with SETCOL-derived sinking rates (Fig. 7 a). Intermediate to high sinking rates measured during the first $10 \mathrm{~d}$ of the experiment were followed by a continuous decrease thereafter. Peaks in the sinking rate which fell outside the general trend were recorded on Days 3 and 17 . High sinking rates on these 2 days coincided with low values of irradiance which were recorded during cloudy conditions on Days $3,17,23$, and 24. Low light levels on these days were measured both during the $24 \mathrm{~h}$ measurement (upper curve in Fig. 7b), and the measurement over the $4 \mathrm{~h}$ period during which phytoplankton were settling in the SETCOL apparatus (lower curve in Fig. 7b). As discussed below, low light levels are suggested to be significant to the interpretation of phytoplankton sinking rates.

A comparison of sinking rates measured using the SETCOL method ( $\Psi_{\text {SETCOL }}$ ), with sinking rates deter-
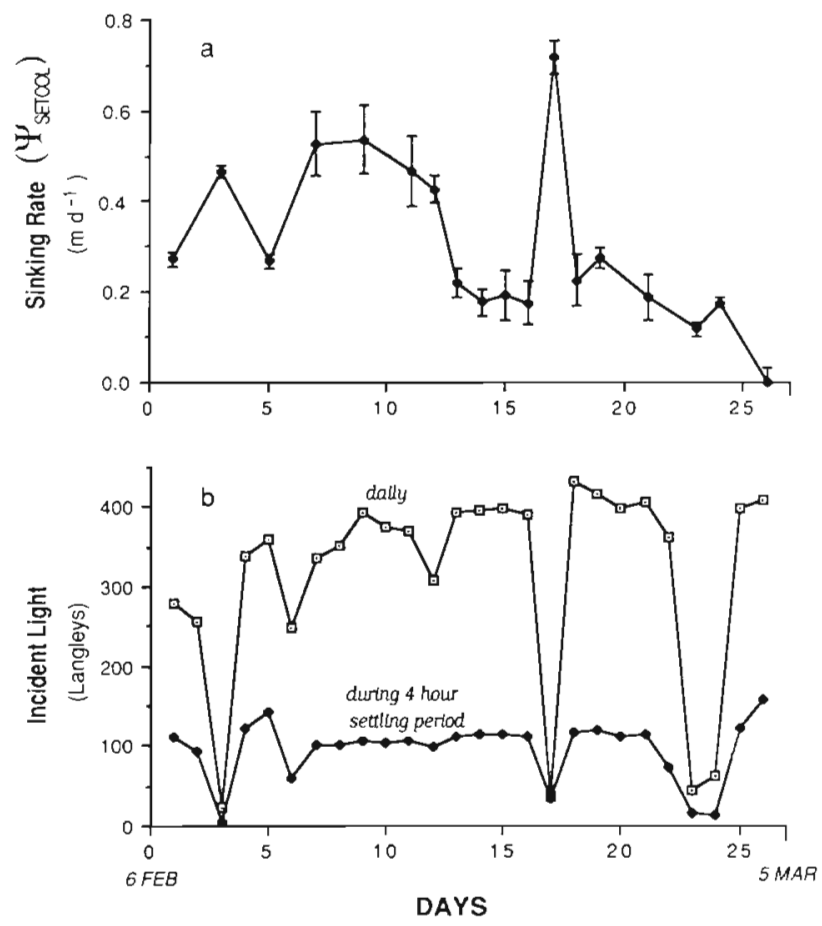

Fig. 7. (a) Whole community sinking rate $\left(\mathrm{m} \mathrm{d}^{-1}\right)$ as measured by the SETCOL method using chlorophyll $a$ as biomass parameter Error bars indicate 1 standard deviation $(n=3)$. (b) Incident light in langleys $\mathrm{d}^{-1}$ (upper curve) and langleys $(4 \mathrm{~h})^{-1}$ (lower curve) over the course of the study. The $4 \mathrm{~h}$ light measurement corresponds to the time period that phytoplankton was settling in the SETCOL apparatus

mined from trap catches ( $\Psi_{\text {TRAP }}$ ), is shown in Table 2. The 2 methods yielded significantly different results $(p<0.01)$ for chlorophyll $a$, phaeopigment, and the 2 most abundant phytoplankton species, Skeletonema costatum and Thalassiosira spp. Significant differences were not found for those groups which were sinking at consistently low rates (Chaetoceros spp., Leptocylindrus minimus, and flagellates)

Table 2. Comparison of average sinking rate as measured from the SETCOL method ( $\psi$ setColi $\mathrm{m}^{-1}$ ) with sinking rate as calculated from trap catches ( $\psi$ rRAp; $\mathrm{m} \mathrm{d}^{-1}$ ); comparison of means by a 2 -tailed $t$-test. $\overline{\mathrm{x}}$ : average sinking rate; $\sigma: 1$ standard deviation; $n$ : number of measurements ( $\psi_{T R, \lambda}$ for Skeletonema based on Days 1 to 17 only)

\begin{tabular}{|c|c|c|c|c|c|c|c|}
\hline Parameter & $\mathrm{x}$ & $\begin{array}{c}\text { SETCO } \\
\sigma\end{array}$ & $n$ & $\mathrm{x}$ & $\psi_{\text {TRAP }}$ & $n$ & $\begin{array}{l}\text { Means sig. diff } \\
\quad(p<0.01)\end{array}$ \\
\hline Chlorophyll a & 0.32 & 0.17 & 17 & 0.89 & 0.21 & 16 & Yes \\
\hline Phaeophytin & 0.19 & 0.17 & 15 & 0.92 & 0.46 & 16 & Yes \\
\hline \multicolumn{8}{|l|}{ Species/Genus/Group } \\
\hline Thalassiosira spp. & 0.55 & 0.36 & 15 & 1.20 & 0.30 & 16 & Yes \\
\hline Skeletonema costatum & 0.07 & 0.11 & 15 & 0.36 & 0.10 & 9 & Yes \\
\hline Chaetoceros spp. & 0.12 & 0.14 & 14 & 0.12 & 0.09 & 12 & No \\
\hline Leptocylindrus minimus & 0.06 & 0.14 & 14 & 0.12 & 0.08 & 16 & No \\
\hline Flagellates $>5 \mu \mathrm{m}$ & 0.11 & 0.08 & 17 & 0.11 & 0.07 & 16 & No \\
\hline
\end{tabular}




\section{DISCUSSION}

The total sedimented organic matter $\left(7.47 \mathrm{~g} \mathrm{C} \mathrm{m}^{-2}\right)$ in the experimental tank over the winter/spring bloom period falls within the range of values for sedimentation in other marine environments. Smetacek et al. (1978) collected a total of $6.2 \mathrm{~g} \mathrm{C} \mathrm{m}^{-2}$ in sediment traps over a $34 \mathrm{~d}$ period during and following a spring bloom in the Bornholm Basin, Baltic Sea. Peinert et al. (1982), working in Kiel Bight, reported the carbon flux resulting from the spring bloom to be $11.5 \mathrm{~g} \mathrm{C} \mathrm{m}^{-2}$ over a $25 \mathrm{~d}$ period. On the continental shelf off the coast of Long Island, Falkowski et al. (1988) estimated a daily flux of $680 \mathrm{mg} \mathrm{C} \mathrm{m}^{-2}$ over a $12 \mathrm{~d}$ period of enhanced primary production resulting in a total flux of $8.2 \mathrm{~g} \mathrm{C} \mathrm{m}^{-2}$. In an earlier study conducted in a MERL mesocosm, Rudnick (1984) estimated the sedimentation from the change of organic carbon in the top $0.5 \mathrm{~cm}$ of the sediment. Based on the total loss of organic carbon in this layer during a period of 10 wk after bloom deposition, he calculated the minimum sedimentation resulting from the winter/ spring bloom to be $17.2 \mathrm{~g} \mathrm{Cm}^{-2}$. Rudnick's value is 2.3 times greater than the flux measured with sediment traps during this experiment. The significantly higher estimate could be due to the fact that in the experiment conducted by Rudnick, $480 \mathrm{l}$ of tankwater were replaced daily with Narragansett Bay water, whereas in this study there was no exchange of tank water. The water exchange could have led to a continuous replenishment of the nutrients in the tank, in particular if the bloom in the mesocosm preceded the bloom in Narragansett Bay.

The fact that the cumulative sinking loss is of the same order of magnitude or higher than the corresponding maximum standing stock for Skeletonema costatum, Thalassiosira spp., and the 2 species of Rhizosolenia (Table 1), indicates that the removal of these species from the plankton is largely attributable to sedimentation. Similar results have been found for several freshwater diatoms by Livingstone \& Reynolds (1981), Reynolds et al. (1982a, b), and Reynolds \& Wiseman (1982). In the case of Chaetoceros spp., the cumulative sinking loss is a small percentage of the maximum standing stock. Therefore, removal must be attributed to other causes such as preferential grazing. The low $\mathrm{S}_{\mathrm{C}} / \mathrm{B}_{\max }$ ratio of Leptocylindrus minimus is due to its very low sinking rates throughout the study. As a result, this species attained its maximum abundance towards the end of the experiment when most other diatoms were already lost from the plankton. Cumulative sinking losses greater than the maximum standing stock are possible since the latter variable is not equivalent to the total production, but may be thought of as the minimum total production (Trimbee \& Harris 1984). This was the case for Thalassiosira spp. Due to a con- tinuously high sinking rate throughout the study (Fig. 6), which resulted in a daily loss of 25 to $35 \%$ of the population, the maximum standing stock amounted to less than half of the total production. The dominance of Thalassiosira spp. in spite of high loss rates indicates that the loss was successfully compensated by high growth rates. The close agreement between cumulative sinking loss and maximum standing stock for $S$. costatum (Table 1), as well as its distinct sinking pattern (Fig. 6), suggest a different strategy for this species. Due to low sinking rates during favorable conditions (daily loss $<10 \%$ ), S. costatum was able to quickly build up its standing stock without losing much of the produced biomass. A drastically increased sinking rate caused the species to disappear from the water column just as rapidly when conditions became unfavorable. A general evaluation of the importance of phytoplankton sedimentation and other loss processes for phytoplankton carbon dynamics during this experiment is presented in Keller \& Riebesell (unpubl.).

Species-specific differences in sinking rates within a diatom community can be accounted for by 2 underlying principles: (1) The overall sinking rate is largely a function of cell size and chain length (Smayda \& Boleyn 1965, 1966a,b, Smayda \& Bienfang 1983). Small diatoms such as Leptocylindrus minimus and the small species of Chaetoceros showed average sinking rates of about $0.1 \mathrm{~m} \mathrm{~d}^{-1}$. The large cells of Thalassiosira spp. on the other hand, sank at average rates several times this value. Depending on the degree of vertical mixing within the water column, these differences in sinking rate lead to differential loss rates which, in addition to other factors, can influence the composition of the phytoplankton community. (2) The prevailing sinking rate of a diatom species can quickly be altered in response to changing environmental conditions. Such a rapid-response sinking behavior on the one hand can be temporary, as was the case for the immediate increase in the sinking rate of several species in coincidence with very low ambient light on Day 17 . On the other hand, such rapid changes can be long-lasting as was observed for Skeletonema costatum (Fig. 6), whose sinking rate drastically increased as of Day 18 and ultimately led to its removal from the water column by Day 22.

While a temporary alteration in sinking rate is likely to be caused by buoyancy-regulating mechanisms within the cell, a protracted increase in sinking rate may be related to the formation of cell aggregates. The mean maximum sinking rate of $4.1 \mathrm{~m} \mathrm{~d}^{-1}$ calculated for Skeletonema costatum in this study is several times higher than the mean maximum sinking rate of $1.35 \mathrm{~m}$ $\mathrm{d}^{-1}$ measured in the laboratory (Smayda \& Boleyn 1966a). This could indicate that the high sinking rates resulted from the formation of aggregates. In fact, $S$. 
costatum chains were frequently observed to be entangled in mucous aggregations which increased in abundance during the decline of the bloom. In contrast, Leptocylindrus minimus did not show a significant change in its sinking behavior (Fig. 6) and was rarely found in trap-collected aggregates. Malone et al. (1983) similarly observed high sedimentation rates of $S$. costatum on the NW Atlantic shelf at times when other species remained in suspension in the surface layer. High sinking rates of $S$. costatum during a bloom in the Baltic Sea were also attributed to aggregate formation by von Bodungen et al. (1981). In studies on natural phytoplankton assemblages, Harrison \& Davis (1979) and Bienfang \& Harrison (1984) found S. costatum to be very sensitive to low ambient silica concentrations while small species of Chaetoceros continued to grow. In this study, silica sank below the detection limit on Day 19. Consequently, it could be hypothesized that the increase in sinking rate of $S$. costatum after Day 18 is a response to silica depletion and could be mediated by aggregate formation.

The influence of light on phytoplankton sinking is indicated by the increasing sinking rates observed for some of the diatom species (Skeletonema costatum, Thalassiosira spp., and Leptocylindrus minimus) on overcast days (Days 3 and 17; Fig. 7). Similar observations were reported by Bienfang (1981b). The relatively greater increase in sinking rate on Day 17 compared to Day 3 could be interpreted as a synergistic response to both low light level and nutrient depletion. The absence of an increase in sinking rate coincident with low light levels on Days 23 and 24 can be related to the shift in the community structure from diatom- to flagellatedominated. A negative effect of light on diatom sinking suggests that buoyancy regulation in this group is an energy-requiring process.

The distinct pattern of the whole-community sinking rate (Fig. 5), as calculated from sediment trap catches $\left(\Psi_{\text {TRAP }}\right)$, can be described in relation to the life cycle of the dominating phytoplankton. A diatom community vigorously growing during the first $10 \mathrm{~d}$ of the experiment is reflected in a decreasing sinking rate (Phase I). A minimum on Day 10 coincides with the peak of the bloom and the exhaustion of dissolved inorganic nutrients. Unfavorable conditions for the diatom community, such as increasing nutrient depletion and consequent slow growth, led to enhanced sinking rates during the following $10 \mathrm{~d}$ (Phase II). A maximum in sinking rate (Day 20) marks the time when the dominating diatom species disappear from the plankton. As the community structure then shifts from diatom- to flagellate-dominated, the sinking rate rapidly decreases (Phase III).

A direct comparison of sinking rate estimates obtained from the SETCOL method ( $\Psi_{\text {SETCOL }}$ ), with those obtained from sediment trap catches ( $\Psi_{\text {TRAP }}$ ), yielded significant differences (Table 2) which could be attributed to a number of factors: (1) Although both $\Psi_{\text {SETCOL }}$ and $\Psi_{\text {TRAP }}$ are expressed in $\mathrm{m} \mathrm{d}^{-1}$, only $\Psi_{\text {TRAP }}$ was calculated on the basis of a $24 \mathrm{~h}$ measurement. $\Psi_{\text {SETCOL }}$ was estimated from a $4 \mathrm{~h}$ settling interval and rates measured during this period were extrapolated to $24 \mathrm{~h}$ to yield a per-day sinking rate. This is valid only if one assumes a constant sinking rate over a $24 \mathrm{~h}$ daily cycle. Since diurnal differences in sinking rate were not measured in this study, a direct comparison of these 2 rates might be questionable. (2) The use of discrete sampling in the SETCOL method carries a bias against the collection of large, rapidly sinking particles (McCave 1975). This can lead to an underestimation of the real sinking rate. (3) The efficiency of sediment traps has received considerable attention in the literature (e.g. Blomqvist \& Håkanson 1981). Traps employed in this study were of cylindrical shape with an aspect ratio (height/diameter) of 4.5 which, according to Gardener $(1977,1980)$ and Blomqvist \& Kofoed (1981), yield high trapping efficiencies. In addition, traps were located below the mixed portion of the water column which further improved the accuracy of the traps. (4) An overestimate of sedimentation rate and consequently of $\Psi_{\text {TRAP }}$ may have been caused by the growth of phytoplankton material collected in the traps. Based on an average residence time of $12 \mathrm{~h}$ for a phytoplankton cell (trap material was collected every $24 \mathrm{~h})$, and an incident light level at the depth of the traps commonly below $0.1 \%$ of the surface radiation, the maximum increase in biomass due to growth in the traps could be no more than 20 to $30 \%$. (5) An important precondition of the SETCOL or homogenous-sample method is the homogenisation of the water sample. This procedure, combined with the collecting and handling of the sample, is likely to cause the break-up of aggregates possibly existing in the undisturbed water. Since aggregates are reported to sink at considerably higher rates than single particles (Shanks \& Trent 1980, Fowler \& Knauer 1986, Asper 1987), the disruption of aggregated particles inherent in the SETCOL method would lead to an underestimate of the true sinking rate.

The algebraic difference $(\delta \Psi)$ between daily estimates of $\Psi_{\text {TRAP }}$ and $\Psi_{\text {SETCOL }}$ plotted against time (Fig. 8) shows small values of $\delta \Psi$ during the build-up of the bloom. This demonstrates that for an actively growing phytoplankton community, the 2 methods yield comparable results. A growing discrepancy between $\Psi_{\text {TRAP }}$ and $\Psi_{\text {SETCOL, }}$ and hence an increasing $\delta \Psi$, occurred during the decline of the bloom. This may have been caused by the formation of the diatom aggregations observed in the sediment traps during this period. While an aggregate-mediated increase in sinking rate 


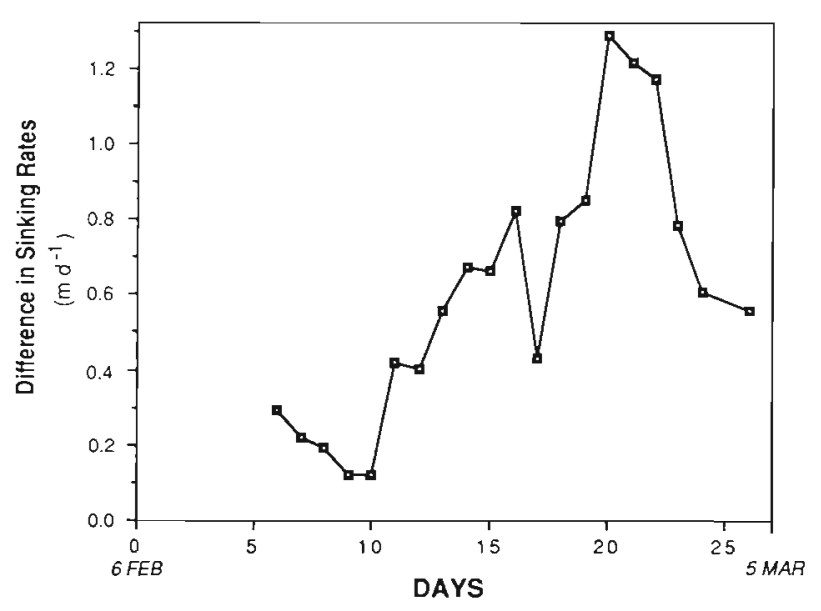

Fig. 8. Arithmetic difference $\left(\delta \Psi=\Psi_{\text {TRAP }}-\Psi_{\text {SETCOL }}\right)$ between sinking rate as calculated from trap catches ( $\Psi_{\text {TRAP }}$ ) and sinking rate as measured with the SETCOL method ( $\Psi_{\text {SETCOL }}$ )

was recorded by the $\Psi_{\text {TRAP }}$ estimate, the SETCOL method, due to the unavoidable destruction of such aggregates, did not detect an increasing sinking rate. It is possible, therefore, that the shortcomings mentioned under points (2) and (5) (i.e. the bias of discrete sampling and the disruption of aggregates) could have caused the SETCOL method to increasingly underestimate the true sinking rate during the decline of the bloom.

In summary, a high loss rate due to the sedimentation of viable, ungrazed phytoplankton cells during the course of the winter/spring bloom led to a rapid disappearance of the diatom population following nutrient depletion. Zooplankton fecal pellets contributed only a minor portion to the total sedimented matter. Assuming the Redfield atomic ratio for the sedimented material, the total carbon sedimentation over the $26 \mathrm{~d}$ experiment was a function of the pre-bloom nutrient concentrations. The strong, short-term variability in sedimentation, which has been documented during the course of phytoplankton blooms in many temperate regions, was found in this study to be caused by a combination of at least 2 mechanisms: while the rate of sedimentation was strongly dependent on the quantity of suspended phytoplankton biomass, this direct relationship was modulated by a characteristic total-community sinking behavior. Species-specific sinking rates showed considerable differences between species and varied over time. The formation of phytoplankton aggregates which was observed during the decline of the bloom had a significant effect on the sinking of certain diatom species. The 2 methods applied to estimate sinking rate yielded comparable results as long as the phytoplankton was present as solitary cells or cell chains. Significant differences were found to occur during the decline of the bloom when phytoplankton aggregates were formed. The bias of discrete sampling and the destruction of aggregates, both inherent in the use of the SETCOL method, are suggested to have caused an underestimation of the in situ sinking rate during this period.

Acknowledgements. I thank Dis C. A. Oviatt and T. J. Smayda for their advice and support throughout this investigation. The study benefited from discussions with Dr A. Keller, Dr D. Stockwell, and T Villareal. The MERL staff, especially E. Klos, C. Heil, S. Kelly, and E. Requintina, are gratefully acknowledged for their technical assistance. The advice and assistance of J. Rines and J. Kiddon are greatly appreciated. Thanks also go to Dr B. Biddanda, Dr P. Bienfang, M. Botros, Dr E. Nöthig, Dr M. Pamatmat, R. Scharek, and Dr V. Smetacek for critical reading of and improvements to the manuscript.

\section{LITERATURE CITED}

Akinana, D. K. (1969). Relative settling rate of Dinoflagellata in relation to their rates of division. Oceanology 9:248-250

Anderson, L. W. J. (1974). Studies on the role of cellular lipids and inorganic ions in controlling sinking rates of Ditylum brightwellii, a marine centric diatom. Ph. D. thesis, Univ. California, Santa Barbara

Asper, V. L. (1987). Measuring the flux and sinking speed of marine snow aggregates. Deep Sea Res. 34:1-17

Bathmann, U. V., Noji, T T., Voss, M., Peinert, R. (1987). Copepod fecal pellets: abundance, sedimentation, and content at a permanent station in the Norwegian Sea in May/June 1986. Mar. Ecol. Prog. Ser. 38: 45-51

Bienfang, P. K. (1979). A new phytoplankton sinking rate method suitable for field use. Deep Sea Res. 26/6A: $719-729$

Bienfang, P. K. (1981a). SETCOL - a technologically simple and reliable method for measuring phytoplankton sinking rates. Can. J. Fish. Aquat. Sci. 38: 1289-1294

Bienfang, P. K. (1981b). Sinking rates of heterogenous temperate phytoplankton populations. J. Plankton Res. 3: 235-253

Bienfang, P. K. (1984). Size structure and sedimentation of biogenic microparticulates in a subarctic ecosystem. J. Plankton Res. 6: 985-995

Bienfang, P. K. (1985). Size structure and sinking rates of various microparticulate constituents in oligotrophic Hawaiian waters. Mar Ecol. Prog. Ser. 23: 143-151

Bienfang, P. K., Harrison, P. J. (1984). Sinking rate response of natural assemblages of temperate and subtropical phytoplankton to nutrient depletion. Mar. Biol. 83: 293-300

Bienfang, P. K., Harrison, P. J., Quarmby, L. M. (1982). Sinking rate response to depletion of nitrate, phosphate, and silicate in four marine diatoms. Mar. Biol. 67: 295-302

Bienfang, P. K., Szyper, J. P., Laws, E. (1983). Sinking rate and pigment responses to light-limitation of a marine diatom: implications to dynamics of chlorophyll maximum layers. Oceanologica Acta 6: 55-62

Billett, D. S. M., Lampitt, R. S., Rice, A. L., Mantoura, R. F. C. (1983). Seasonal sedimentation of phytoplankton to the deep-sea benthos. Nature, Lond. 302: 520-522

Blomqvist, S., Håkanson, L. (1981). A review on sediment traps in aquatic environments. Arch. Hydrobiol. 91: $101-132$

Blomqvist, S., Kofoed C. (1981). Sediment trapping - a subaquatic in situ experiment. Limnol. Oceanogr. 26: 585-590

Bodungen, B. von, Bröckel, K. von, Smetacek, V., Zeitzschel, B. (1981). Growth and sedimentation of the phytoplankton 
spring bloom in the Bornholm Sea (Baltic Sea). Kieler Meeresforsch., Sonderh. 5: 49-60

Christensen, H., Kanneworff, E. (1985). Sedimenting phytoplankton as major food source for suspension and deposit feeders in the Øresund. Ophelia 24: 223-244

Davies, J. M., Payne, R. (1984). Supply of organic matter to the sediment in the northern North Sea during a spring phytoplankton bloom. Mar. Biol. 78: 315-324

Deuser, W. G., Ross, E. H. (1980). Seasonal change in the flux of organic carbon to the deep Sargasso Sea. Nature, Lond. 283: $364-365$

Dinsdale, M. T., Walsby, A. E. (1972). The interrelations of cell turgor pressure, gas vacuolation and buoyancy in a bluegreen alga. J, exp. Bot. 23: 561-572

Donaghay, P. L., Klos, E. (1985). Physical, chemical and biological responses to simulated wind and tidal mixing in experimental marine ecosystems. Mar. Ecol. Prog. Ser. 26 $35-45$

Eppley, R. W., Holmes, R. W., Paasche, E. (1967a). Periodicity in cell division and physiological behavior of Ditylum brightwelli, a marine planktonic diatom, during growth in light-dark cycles. Arch. Mikrobiol. 56: 305-323

Eppley, R. W. Holmes, R. W., Strickland, J. D. H. (1967b). Sinking rate of marine phytoplankton measured with a fluorometer. J. exp. mar. Biol. Ecol. 191-208

Eppley, R. W., Reid, F. M. H., Strickland, J. D. H. (1970). The ecology of the plankton off La Jolla, California in the period April through September 1967. Part III. Estimates of phytoplankton growth rate, and primary production. Bull. Scripps Inst. Oceanogr. 17. 33-42

Falkowski, P. G., Flagg, C. N., Rowe, G. T., Smith, S. L., Whitledge, T E., Wirick, C. D. (1988). The fate of a spring phytoplankton bloom: export or oxidation? Cont. Shelf Res, 8: $457-484$

Fowler, S. W., Knauer, G. A. (1986). Role of large particles in the transport of elements and organic compounds through the oceanic water column. Prog. Oceanogr. 16: 147-194

Gardner, W. D. (1977). Fluxes, dynamic and chemistry of particulates in the ocean. Ph. D. thesis, M.I.T./Woods Hole Oceanogr. Inst., Joint Program in Oceanography

Gardner, W D. (1980). Field assessment of sediment traps. J. mar Res. 38: 41-52

Hargrave, B. T., Taguchi, S. (1978). Origin of deposited material sedimented in a marine bay. J. Fish. Res. Bd Can. 35: $1604-1613$

Harrison, P. J., Davis, C. O. (1979). The use of outdoor phytoplankton continuous cultures to analyze factors influencing species selection. J. exp. mar. Biol. Ecol. 41 - 9-23

Hasle, G. R. (1978). The inverted microscope method. In: Sournia, A. (ed.) Phytoplankton manual. UNESCO Monographs on Oceanographic Methodology 6: 88-96

Honjo, S. (1982). Seasonality and interaction of biogenic and lithogenic particulate flux at the Panama Basin. Science 218: 883-884

Jaques, G., Hoepffner, N. (1984). Sinking rates of subantarctic neritic phytoplankton. C. r Acad. Sci. Paris, 299, Série III, no. 14: $581-585$

Jewson, D. H., Rippey, B. H., Gilmore, W. K. (1981). Loss rates from sedimentation, parasitism and grazing during the growth, nutrient limitation and dormancy of a diatom crop. Limnol. Oceanogr. 26: 1045-1056

Johnson, T. O., Smith, W. O. (1986). Sinking rates of phytoplankton assemblages in the Weddell Sea marginal ice zone. Mar Ecol. Prog. Ser. 33: 131-137

Kalff, J., Knoechel, R (1978). Phytoplankton and their dynamics in oligotrophic and eutrophic lakes. Ann. Rev. Ecol. Syst. 9: 475-495
Kelly, S. P., Beach, R. B. (1986). Nutrient standing stock. In: Lambert, E. E., Oviatt, C. A. (ed.) Manual of biological and geochemical techniques in coastal areas. MERL Series, Report No.1, 2nd edn. Univ. Rhode Island, Kingston, p. 91-113

Kovala, I E., Larrance, J. D. (1966). Computation of phytoplankton cell numbers, cell volume, cell surface, and plasma volume per liter from microscopical counts. Spec. Rep. No.38. Univ. Washington, Dept. Oceanogr., Ref. M66-1

Lampitt, R. S. (1985). Evidence for the seasonal deposition of detritus to the deep-sea floor and its subsequent resuspension. Deep Sea Res. 32: 885-897

Lännergren, C. (1979). Buoyancy of natural populations of marine phytoplankton. Mar. Biol. 47: 177-189

Livingstone, D., Reynolds, C. S. (1981). Algal sedimentation in relation to phytoplankton periodicity in Rostherne Mere. Br. phycol. J. 16: 195-206

Malone, T. C., Falkowski, P. G., Sawyer Hopkins, T., Rowe, G. T., Whitledge, T. E. (1983). Messoscale response of diatom populations to a wind event in the plume of the Hudson River. Deep Sea Res. 30: 149-170

McCave, I. N. (1975). Vertical flux of particles in the ocean. Deep Sea Res. 22: 491-502

Parsons, T R., Takahashi, M., Hargrave, B. (1984). Biological oceanographic processes, 3rd edn. Pergamon Press, Oxford

Peinert, R., Saure, A., Stegmann, P., Stienen, C., Haardt, H., Smetacek, V. (1982). Dynamics of primary production and sedimentation in a coastal ecosystem. Neth. J. Sea Res. 16: 276-289

Redfield, A. C. (1958). The biological control of chemical factors in the environment. Am. Sci. 46: 205-220

Reynolds, C. S. (1973). Growth and buoyancy of Microcystis aeruginosa Kutz. emend. Elenkin in a shallow eutrophic lake. Proc. R. Soc. Lond. B. 184: 29-50

Reynolds, C. S. (1976). Sinking movements of phytoplankton indicated by a simple trapping method. II. Vertical activity ranges in a stratified lake. Br phycol. J. 11: 293-303

Reynolds, C. S., Morison, H. R., Butterwick, C. (1982a). The sedimentary flux of phytoplankton in the south basin of Windermere. Limnol. Oceanogr. 27: 1162-1175

Reynolds, C. S., Thompson, J. M., Ferguson, A. J., Wiseman, W. W. (1982b). Loss processes in the population dynamics of phytoplankton in closed limnetic systems. J. Plankton Res. 4: 561-600

Reynolds, C. S., Wiseman, S. W. (1982). Sinking losses of phytoplankton in closed limnetic systems. J. Plankton Res. 4: $489-522$

Rothwell, G. N., Bienfang, P. K. (1978). MARS - a new instrument for measuring phytoplankton sinking rate. Mar. Technol. Soc. J. 12: 13-17

Rudnick, D. T (1984). Seasonality of community structure and carbon flow in narragansett Bay sediments. Ph. D. thesis, Univ. Rhode Island, Kingston

Shanks, A. L., Trent, J. D. (1980). Marine snow: sinking rates and potential role in vertical flux. Deep Sea Res., 27 A: $137-143$

Smayda, T J. (1980). Phytoplankton species sucession. In. Morris, I. (ed.) The physiological ecology of phytoplankton. Blackwell Scientific Publication, Oxford, p. 493-570

Smayda, T. J., Bienfang, P. K. (1983). Suspension properties of various groups of phytoplankton and tintinnids in an oligotrophic, subtropical system. P.S.Z.N.I. Mar Ecol. 4: 289-300

Smayda, T. J., Boleyn, B. J. (1965). Experimental observations on the flotation of marine diatoms. I. Thalassiosira cf nana, 
Thalassiosira rotula, and Nitzschia seriata. Limnol. Oceanogr. 10: 449-509

Smayda, T. J., Boleyn, B. J. (1966a). Experimental observations on the flotation of marine diatoms. II. Skeletonema costatum and Rhizosolenia setigera. Limnol. Oceanogr. 11 18-34

Smayda, T J., Boleyn, B. J. (1966b). Experimental observations on the floatation of marine diatoms. III. Bacteriastrum hyalinum and Chaetoceros lauderi. Limnol. Oceanogr 11 $35-43$

Smetacek, V. S. (1980). Annual cycle of sedimentation in relation to phytoplankton ecology in Western Kiel Bight. Ophelia, Suppl. 1 65-76

Smetacek, V S. (1984). The supply of food to the benthos. In: Fasham, M. J. (ed.) Flows of energy and materials in marine ecosystems: theory and practice. Plenum Press, New York, p. 517-548

Smetacek, V. S. (1985). Role of sinking in diatom life-history cycles: ecological, evolutionary, and geological significance. Mar. Biol. 84: 239-251

Smetacek, V. S., Bröckel, K. von, Zeitzschel, B. W., Zenk, W. (1978). Sedimentation of particulate matter during a phytoplankton spring bloom in relation to the hydrographical regime. Mar. Biol. 47: 211-226

Steele, J. H., Yentsch, C. S. (1960). The vertical distribution of chlorophyll. J. mar biol. Ass. U. K. 39: 217-226

This article was submitted to the editor
Strickland, J. D. H., Parsons, T. R. (1972). A practical handbook of seawater analysis, 2nd edn. Bull. Fish. Res. Bd Can. 167: 1-310

Titman, D., Kilham, P. (1976). Sinking in freshwater phytoplankton. Some ecological implications of cell nutrient status and physical mixing processes. Limnol. Oceanogr. 21: 409-4 19

Trimbee, A. M., Harris, G. P. (1984). Phytoplankton population dynamics of a small reservoir: use of sedimentation traps to quantify the loss of diatoms and recruitment of summer bloom-forming blue-green algae. J. Plankton Res. 6: $897-918$

Utermöhl, H. (1958). Zur Vervollkommnung der quantitativen Phytoplankton-Methodik. Mitt. int. Verein theor. angew. Limnol. 9: 1-38

Walsby, A. E. (1969). The permeability of blue-green algal gas-vacuole membranes to gas. Proc. R. Soc. Lond. B. 173: 235-255

Walsby, A. E. (1970). The nuisance algae: curiosities in the biology of planktonic blue-green algae. Water Treat. Exam. 19: 359-373

Wassmann, P. (1983). Sedimentation of organic and inorganic particulate material in Lindaspollene, a stratified, landlocked fjord in western Norway. Mar. Ecol. Prog. Ser. 13: $237-248$

Manuscript first received: November 24, 1988

Revised version accepted: March 3, 1989 